\title{
Biomass Production and Nutrient Content Animal Feed in Kuantan Singingi District
}

\author{
Infitria a, Pajri Anwar $b$, Jiyanto ${ }^{c}$ \\ abc Departement of Animal Science, Faculty of Agriculture, Kuantan Singingi Islamic University - Riau \\ email: an infitria.sumeh@gmail.com
}

\begin{tabular}{l}
\hline A R T I C L E I N F O \\
\hline Article history: \\
Received 22 December 2020 \\
Revised 5 January 2021 \\
Accepted 28 July 2021 \\
Available online 30 July \\
2021 \\
\hline
\end{tabular}

Keywords:

Forages,

Nutrient,

Cruide Protein

Cruide Fiber,

Biomassa Production,

IEEE style in citing this article:

Infitria, P. Anwar and Jiyanto " Biomassa

Production and nutrient content of Animal feed in Kuantan Singingi districts"

Jurnal Ternak : Jurnal Ilmiah

Fakultas Peternakan

Universitas Islam

Lamongan, vol. 12 , no. 1 ,

pp. $22-27,2021$.

\begin{abstract}
A B S T R A C T
Forage is a major requirement in increasing ruminant livestock production. Kuantan Singingi Regency is a district that has quite a lot of grasslands whose production and quality of forage are unknown, so this study aims to determine the production and nutritional content of forages in Kuantan Singingi Regency. This research consisted of three stages, survey (field observation and location determination), forage sampling, and nutrient quality analysis. Forage samples were taken in 4 subdistricts, namely the Districts of Central Kuantan, Sentajo Raya, Gunung Toar and Kuantan Mudik. 5 locations were taken for each sub-district, 4 points for each location were taken. The tools used for forage sampling consisted of a $0.5 \times 0.5 \mathrm{~m} 2$ quadrant, grass shears, sickle, plastic bags of size 10 and size $2 \mathrm{~kg}$, sacks, plastic ropes, and stationery. The analysis of nutrient quality using forage samples in 4 districts using proximate analysis. Forage production data and forage nutrient content were statistically analyzed using analysis of variance (ANOVA). The results showed that there were differences in production and nutrient content in each sub-district $\mathrm{P}<0.05$. Fresh biomass production showed a significant effect of $\mathrm{P}<0.05$. Fresh forage production ranged from $111.67 \pm 16.45 \mathrm{Kg}$ $\mathrm{FW} /$ ha/day, while dry forage production ranged from $23.80 \pm 5.29 \mathrm{Kg}$ to $187.04 \pm 67.35 \mathrm{Kg}$. The conclusion of this study is that the production and nutritional content of forage in Kuantan Singingi Regency is relatively low, the production of DW/ha/day is $23.80-40.35 \mathrm{Kg}$, and the $\mathrm{CP}$ ranges from $7.85-10.55 \%$ DW.
\end{abstract}

\section{Introduction}

Kuantan Singingi or Kuansing Regency is one of the regencies in Riau Province whose existence is bordered by Jambi Province and West Sumatra. This area has many plantation areas as in general, the Kuansing people are active as oil palm and rubber farmers. Based on BPS data, 2018 Kuansing has plantation area of 411,693 hectares. In addition to the area of Kuansing plantations, it also has about 1801 hectares of grassland [1], This shows that Kuansing Regency has the potential for land availability and forage sources that are large enough to support the development of ruminants. Grassland needs to be managed and calculated forage so that it can be evaluated for improving livestock and forage productivity [2]. 
Forage is the most important main component in livestock productivity. Forage, originating from plantations and grasslands in Kuansing Regency, is the main source of forage for ruminan animal feed. The resources available in the nature is related to livestock business [3]. The pasteur needs to know the botanical composition and storage capacity [4]. The natural resources such as forage are the main factors for the sustainability of livestock business [5]. Generally, people in Kuansing raise their livestock by releasing them, meanwhile, some of them are kept in cages in the afternoon. Cattle are housed at night with a pasture fattening system [6]. Nonetheless, until recently, these plantations and grasslands have not been studied in an effort to use them for the development of beef cattle, so the quantity and quality of feed that can be produced in Kuansing is unknown. In addition, at the recent time, there is no data on the amount of forage production in Kuansing Regency, so that the biomass production and nutritional content of the forage are not known. Therefore, the purpose of this study is to determine the production of biomass and nutrient content of forage that grows in Kuansing Regency.

\section{State of the Art}

\subsection{Production and Greenery Nutrition}

Forage production is the ability of a land to produce forage in a field. A land has a different production depending on the area of land, the type of forage and nutrient content. Forage production of a different land is influenced by management factors such as environmental conditions and seasons. The seasons affect the production and nutritional content of forages [7]. Forage productivity is influenced by land factors that have the availability of forage for livestock [8].

\section{Method}

\section{Research Procedure}

The research was carried out in Kuantan Singingi Regency, Riau Province from July to August 2020. The research was conducted in four sub-districts named Kuantan Tengah District, Sentajo Raya District, Gunung Toar District and Kuantan Mudik District. The determination of the location by purposive sampling method was deliberately based on considerations of regional location and strata [9]. The study used the RAL method, a completely randomized design with four treatments and five replications. This research was conducted in 3 (three) stages, the first stage was to conduct a survey by direct observation to the 4 sub-districts located in Kuantan Singingi district, they are the districts of Kuantan Tengah, Sentajo Raya, Gunung Toar and Kuantan Mudik. The second stage was to take forage samples which were divided into 4 sub-districts with each sub-district taken as many as 5 villages as sampling locations, each location was taken 5 sample points using a $0.5 \times 0.5 \mathrm{~m} 2$ quadrant. The third stage was calculating forage biomass production and preparing samples for analysis of nutrient content. The analysis of nutrient content was conducted at the UNAND Padang Campus.

\section{Sampling Location Determination Survey}

The survey was conducted to observe the land that would be used as a research sampling location and to get a clearer picture of the location of each area. The survey was carried out in four selected districts. 


\section{Forage Sampling}

Forage sampling consisted of 4 sub-districts, each sub-district took 5 villages, each village took 5 location points. Side taking with a quadrant (plate meter) measuring $0.5 \times 0.5 \mathrm{~m} 2$. The quadrants were placed diagonally at random at each selected point. Furthermore, all forage plants that were in the quadrant were cut as high as $5-10 \mathrm{~cm}$ from the ground surface or until they were snatched by livestock [10]. The forage that has been cut is then put into a plastic bag, then tied and labeled. The forage is then brought to the laboratory to be weighed.

\section{Forage Biomass Production Calculation and Sample Preparation for Nutrient Content Analysis}

The forage that has been weighed freshly to calculate the product in the biomass. The biomass production was calculated by the formula [11]. The analysis of the nutrient content began with cutting the plant 2 to $3 \mathrm{~cm}$ long with a knife (machete) and using a cutting board as the base. The forage that have been cut was composited to mix evenly and then put into aluminum foil which was designed like a box with a size of $27 \times 11.5 \times 5.5 \mathrm{~cm}$ and weighed until the weight reached $150 \mathrm{~g}$ with 3 replications. The plant samples were then dried in an oven at a temperature of $60-65 \mathrm{oC}$ or in sunlight for 48 hours or until the stems of the plants were easily broken. The forage that have been in the oven was then weighed dry and mashed using a blender until it become flour.

\section{The Analysis of Food Substances}

Forage samples that had been in the form of flour were then analyzed for nutrient content. The content of food substances analyzed were Dry Matter (BK), Ash, Crude Protein (PK), Crude Fiber (SK) [12].

\section{Data Analysis}

The data were statistically analyzed using a completely randomized design (CRD) with 4 treatments and 5 replications using analysis of variance (ANOVA) [13]. Data processing using SPSS 20.0 Statistical Software.

\section{Results and Discussion}

The Forage Biomass Production

Table 1. Biomass Production and Carrying Capacity based on Dry Matter

\begin{tabular}{lccccc}
\hline \multirow{2}{*}{ District } & $\begin{array}{c}\text { Area of } \\
\text { Land }\end{array}$ & \multicolumn{2}{c}{ Biomass Production $(\mathrm{kg})$} & \multicolumn{2}{c}{ Carrying Capacity } \\
\cline { 2 - 6 } & Ha & FW/ha/day & DW/ha/day & ST/ha & ST/area \\
\hline KT & 1025,56 & $187.04 \pm 67.35 \mathrm{a}$ & $40.35 \pm 17.05 \mathrm{a}$ & $4.98 \pm 2.10 \mathrm{a}$ & $5901.90 \pm 10472.62$ \\
SR & 1018,80 & $112.39 \pm 21.62 \mathrm{~b}$ & $23.80 \pm 5.29 \mathrm{~b}$ & $2.94 \pm 0.65 \mathrm{~b}$ & $3126.73 \pm 2421.14$ \\
KM & 4026,20 & $111.67 \pm 16.45 \mathrm{~b}$ & $24.15 \pm 5.96 \mathrm{~b}$ & $2.98 \pm 0.74 \mathrm{~b}$ & $12864.73 \pm 21651.79$ \\
GT & 856,20 & $135.03 \pm 26.83 \mathrm{ab}$ & $30.16 \pm 10.71 \mathrm{ab}$ & $3.72 \pm 1.32 \mathrm{ab}$ & $3599.57 \pm 3614.86$ \\
\hline
\end{tabular}

Keterangan : KT (Kuantan Tengah), SR (Sentajo Raya), KM (Kuantan Mudik), GT (Gunung Toar)

The forage biomass production was forage production produced by a land or area at a certain time. The forage biomass production can be calculated per day, month and year. The forage biomass production per ton/ha/year was obtained by calculating the production of fresh forage in one year. 
The fresh biomass production was used to determine the production of grass on a land within one year. The fresh forage production in Table 1. showed the different production in each sub-district. The fresh biomass production showed a significant effect of $\mathrm{P}<0.05$. The production of fresh forage ranged from $111.67 \pm 16.45 \mathrm{FW} /$ ha/day to $187.04 \pm 67.35 \mathrm{FW} /$ ha/day, while production of forage $\mathrm{DW} /$ ha/day ranged from $23.80 \pm 5.29$ to $187.04 \pm 67.35$. The highest forage production is found in the village of KT Kuantan Tengah. The differences in fresh forage production per FW/ha/day and DW/ha/day were caused by the diversity of forage grown in the field and management. Good management would produce maximum forage production. [7] stated that the growth and production of forage is influenced, climate and management. In addition, seasonal factors also affect forage production. Season affects biomass production and nutritional quality of forage feeds [7]. Natural forage production is also relatively decreased in the dry season so that it will directly affect livestock productivity.

The carrying capacity is the ability of a land to accommodate livestock to be reared. The holding capacity of livestock in Kuansing Regency ranged from 2.94 to 4.98 ST/ha, while the holding capacity based on land area ranged from 3126.73 to $12864.73 \mathrm{ST}$. The storage capacity was closely related to the production of forage biomass. The size of the carrying capacity of a land was determined by the production of forage biomass produced. The higher the forage production, the higher the capacity. [14] stated that the number of livestock carrying capacity on a land was determined by the high level of forage production per unit area of land.

The yield of dry forage biomass production per day when compared to the yield at BPTU-HPT Padang Mengatas looks lower, this is presumably because forage management in Kuansing Regency has not been managed properly and forage is allowed to grow without treatment such as fertilizer. In addition, the natural forage factor that grows in the field and forage that grows around oil palm plantations, rubber plantations, swamps and vacant land that has not been managed, so that forage production in Kuansing Regency is not optimal. The dry biomass production of BPTU-HPT Padang Mengatasa is $116.70 \mathrm{Kg} / \mathrm{DW} /$ ha/day in the rainy season and $73.22 \mathrm{Kg} \mathrm{DW} / \mathrm{ha} /$ day in the dry season, with a land area of $208.41 \mathrm{Ha}[7]$.

Forage Nutrient Content

Table 2. Biomass Production and Forage Nutrient Content ini Kuantan Singingi District

\begin{tabular}{cccccc}
\hline \multirow{2}{*}{ District } & Water Content & DM content & \multicolumn{3}{c}{ Nutrient (\% DM) } \\
\cline { 4 - 6 } & $(\% \mathrm{FW})$ & $(\% \mathrm{FW})$ & Ash & $\mathrm{CP}$ & $\mathrm{CF}$ \\
\hline KT & $78.78 \pm 1.51$ & $21.22 \pm 1.51$ & $9,43 \pm 1.19 \mathrm{~b}$ & $10.55 \pm 1.57 \mathrm{a}$ & $25.76 \pm 1.07 \mathrm{a}$ \\
SR & $78.88 \pm 2,31$ & $21,12 \pm 2,31$ & $9,90 \pm 1.48 \mathrm{~b}$ & $9.78 \pm 0.91 \mathrm{ab}$ & $25.96 \pm 0.78 \mathrm{~b}$ \\
KM & $78.57 \pm 3.01$ & $21.43 \pm 3.01$ & $8,76 \pm 0.93 \mathrm{ab}$ & $7.85 \pm 1.12 \mathrm{bc}$ & $25.82 \pm 0.85 \mathrm{~b}$ \\
GT & $78.05 \pm 3.56$ & $21,95 \pm 3.56$ & $7,33 \pm 0.68 \mathrm{a}$ & $8.63 \pm 0.30 \mathrm{c}$ & $28.09 \pm 1.26 \mathrm{~b}$ \\
\hline
\end{tabular}

Note: Different superscripts in the same column show different effects. KT (Kuantan Tengah), SR (Sentajo Raya), KM (Kuantan Mudik), GT (Gunung Toar). CP(Crude protein) CF (Crude fiber). DM (Dry Matter). FW (Fresh Weight).

Nutrient content is an important factor in evaluating forage. The nutritional content of forages growing in plantation and grassland areas in each sub-district is presented in Table 2. Based on statistical analysis of forages in Kuansing Regency, it looks different $(P<0.05)$, on the nutritional quality of $\mathrm{CP}, \mathrm{CF}$ and Ash.

The results of the analysis of the nutrient content of forages in Kuantan Singingi Regency look varied. The high and low nutrient content of forage is influenced by the type of forage. The results 
showed that the dry matter forage ranged from $21.12 \pm 2.31$ to $21.95 \pm 3.56$. This shows that the $\mathrm{CP}$ forage in Kuansing Regency does not show a significant difference, while the CP shows a significant effect $(\mathrm{P}<0.05) . \pm 1.12$. The $\mathrm{CP}$ content of natural forages is not much different from the CP content in other areas. This result is not far from the results of research [15] in [7] which reported that the content of grass land has a $\mathrm{BK}$ content ranging from $16.01 \%$ to $80.41 \%$ while the $\mathrm{CP}$ content ranges from $2.71 \%$ to $9.48 \%$. This $\mathrm{CP}$ content fluctuates according to changes in seasons, age of forage and natural conditions. At the end of the dry season the $\mathrm{CP}$ forage is $2.26 \%$ and the rainy season is $8-10 \%$.

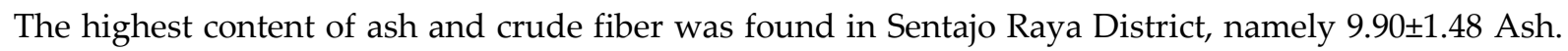
The highest crude fiber was found in Gunung Toar District, namely $28.09 \pm 1.06$ and the lowest was found in Central Kuantan District, namely 25.76 \pm 1.07 . The nutritional quality of forage depends on the composition and type of forage that grows in the field, in addition to the factors of plants growing in nature, soil conditions, water availability, fertilization, cultivated plants and also the cutting phase of forage. [7] stated that the high and low content of nutrients in grass land was caused by environmental factors, rainfall, fertilization and also the difference in forage cutting time. [16] said that the factor causing the low crude protein content and high crude fiber content was the undegrazing condition so that the plant vegetation experienced aging.

The nutritional content of forage in Kuansing Regency was relatively low, this was because the forage comes from natural forage that grows in the field. [16] stated that the productivity of livestock fed natural grass forage was not sufficient for the nutritional needs of livestock [17] and [18] stated that livestock nutrients are not sufficient and cannot be fulfilled if it comes from forage that grows in the field/natural grass, in addition, livestock during the growth period show low body weight growth. The nutrient content of the forage in Kuansing Regency was almost the same as the study [7], higher than the study [16] and lower than the study [11] , that the nutrient content of forage in the grazing fields of BPTU-HPT Padang Mengatas was around 9.24 in the rainy season and 11.50 in the dry season [7], CP 6.31-6.63 nutrient content of forage growing in North Lore Pasture, Poso District [16] , nevertheless, compared to the previous study, [11] the CP ranged from 7.72-18.7\%. In addition [19] stated that the nutritional content of natural grass forage in BKPH Kebasen Banyumas was DM 24.68\%, ash 14.26\%, CP $8.90 \%$ and CF $33.31 \%$. The high and low protein content of forage in Kuansing Regency was thought to be due to the various types of forage and management that has not been managed properly and fertilization factors. It was also caused by the influence of the season. Forage production which was influenced by different seasons was one of the obstacles in raising livestock[20].

\section{Conclusions}

Biomass production and forage nutrient content in Kuantan Singingi Regency are relatively low, with production of DW/ha/day $23.80-40.35 \mathrm{Kg}$, and CP ranging from $7.85-10.55 \% \mathrm{DM}$.

\section{Acknowledgment}

The author's gratitude goes to the Kemenristek Dikti trough Hibah PDP 2020 No 8/E1/KPT/2020.

\section{References}

[1] BPS, Kabupaten Kuantan Singingi Dalam Angka. kuansing, 2018.

[2] V.H. Hae, M.M Kleden, and S.T. Temu, "Produksi, Komposisi Botani dan Kapasitas Tampung Hijauan pada padang Penggembalaan Alam Awal Musim Kemarau," vol. 7, no. 1, pp. 14-22, 2020.

[3] N.M. Sengkey, A.H.S. Salendu, E. Wantesan, P.O.V. Walelelng, "Potensi Pengembangan 
Ternak Sapi Potong Di Kecamatan Tompaso Barat," Zootec, vol. 37, no. 2, p. 350, 2017, doi: 10.35792/zot.37.2.2017.16155.

[4] O. Yoku, A. Supriyantono, T. widayati, and I. Sumpe, "Produksi Padang Penggembalaan Alam Dan Potensi Pengembangan Sapi Bali Dalam Mendukung Program Kecukupan Daging Di Papua Barat," Pastura, vol. 3, no. 2, pp. 102-105, 2014, doi: 10.24843/Pastura.2014.v03.i02.p11.

[5] R.K. Dewi, "Analisis Potensi Wilayah Pengembangan Ternak Ruminansia Di Kabupaten Lamongan," J. ternak, vol. 09, no. 2, 2018.

[6] H. Rusnan, C.H.L.Kaunang, and Y.1.R.Tulung, "Analisis Potensi Dan Strategi Pengembangan Sapi Potong Dengan Pola Integrasi Kelapa-Sapi Di Kabupaten Halmahera Selatan Provinsi Maluku Utara," Zootec, vol. 35, no. 2, p. 187, 2015, doi: 10.35792/zot.35.2.2015.7433.

[7] Muhajirin, Despal, and Khalil, "Pemenehuhan Kebutuhan Nutrient Sapi Potong Bibit Yang Digembalakan Di Padang Mengatas," vol. 104, no. 1, pp. 9-20, 2017.

[8] R.K. Putra, H.P. Nastiti, Y.H. Manggol, "Komposisi Botani Dan Produksi Hijauan Makanan Ternak Padang Penggembalaan Alam Di Desa Letneo Kecamatan Insana Kabupaten TTU," Nukl. Peternak., vol. 5, no. 1, pp. 42-48, 2018.

[9] F.M. Ferianita, Metode Sampling Bioekologi. jakarta: bumiaksara, 2006.

[10] M. Junaidi and D. Sawen, "Keragaman Botanis dan Kapasitas Tampung Padang Penggembalaan Alami Kabupaten Yapen," J. Ilmu Peternak. dan Vet. ..., vol. 5, no. 2, 2010, [Online]. Available: https://journal.fapetunipa.ac.id/index.php/JIPVET/article/view/46.

[11] Infitria and Khalil, "Studi Produksi Dan kualitas Hijauan Dilahan Padang Rumput Upt peternakan Universitas Andalas," Bul. Makanan Ternak, vol. 101, no. 1, pp. 25-33, 2014.

[12] AOAC, official method of analysis 17Th eddition. arlington: Assoc off Ana Chem, 2000.

[13] M. S. A.A. Mattik, Perancangan percobaan dan Aplikasi SAS dan Minitab, 1st ed. bogor: IPB Press, 2002.

[14] Y.U. Hawolambani, H.P. Nastiti, dan Y.H.M anggol, “Produksi Hijauan Mkanan Ternak dan Komposisi Botani Padang Penggembalaan Pada Musim Hujan di Kecamatan Amarasi Barat Kabupaten Kupang," vol. 2, no. 1, pp. 59-65, 2015.

[15] A.E. Manu, "produktivitas padang penggembalaan saban timur timur barat," pastura, vol. 3, no. 1, pp. 25-29, 2013.

[16] Damry, "Produksi dan Kandungan Nutrien Hijauan Padang Penggembalaan Alam di Kecamatan Lore Utara," vol. 16, no. 4, pp. 296-300, 2009.

[17] A. Marsetyo, Priyanti, and Pamungkas, Growth perfomance of young bali cattle under varoius feeding management. Yogyakarta, Indonesia: Gadjah Mada Univerrsity, 2006.

[18] ACIAR, "Strategies to increase growth of weaned bali cattle," 2008.

[19] Bahrun, T. Widyastuti, N. Hidayat, D. A. Saputra, and D. R. Putri, “Daya Dukung Hijauan Rumput Alam Sebagai Pakan Ternak Sapi Potong di BKPH Kebasem, Banyumas," Pros. Semin. Teknol. dan Agribisnis Peternak. VI Pengemb. Sumber Daya Genet. Ternak Lokal Menuju Swasembada Pangan Hewani ASUH, pp. 115-119, 2018.

[20] N. Umami, E. Damayanti, Potensi dan Produksi Hijauan Pakan Ternak di Lahan Pertanian Banyusoco, Playen, Gunung Kidul. Yogyakarta, Indonesia: Fakultas Peternakan UGM, 2016. 